\title{
A META-ANALYSIS OF FRAUD, WASTE AND ABUSE DETECTION METHODS IN HEALTHCARE
}

\author{
R. Ikono ${ }^{1, *}$, O. Iroju ${ }^{2}$, J. Olaleke ${ }^{3}$ and T. Oyegoke ${ }^{4}$

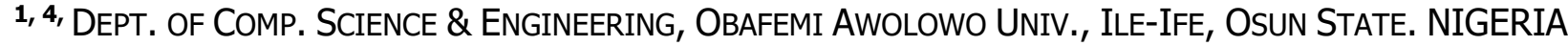 \\ 2, 3, Department Of Computer SCIENCE, Adeyemi College of Education, ONdo, ONdo State. NIGERIA \\ E-mail addresses: ${ }^{1}$ rhoda_u@yahoo.com, 2 irojuolaronke@gmail.com, 3 shollyjane@yahoo.com, \\ 4 temitayooyegoke@yahoo.com
}

\begin{abstract}
Fraud, waste and abuse have been a concern in healthcare system due to the exponential increase in the loss of revenue, loss of reputation and goodwill, and a rapid decline in the relationship between healthcare providers and patients. Consequently, fraud, waste and abuse result in a high cost of healthcare services, decreased quality of care, and threat to patients' lives. Its enormous side effects in healthcare have attracted diverse efforts in the healthcare industry, data analytics industry and research communities towards the development of fraud detection methods. Hence, this study examines and analyzes fraud, waste and abuse detection methods used in healthcare, to reveal the strengths and limitations of each approach. Eighty eight literatures obtained from journal articles, conference proceedings and books based on their relevance to the research problem were reviewed. The result of this review revealed that fraud detection methods are difficult to implement in the healthcare system because new fraud patterns are constantly developed to circumvent fraud detection methods. Research in medical fraud assessment is limited due to data limitations as well as privacy and confidentiality concerns.
\end{abstract}

\section{Keywords: abuse, fraud, healthcare, waste, fraud detection methods}

\section{INTRODUCTION}

The healthcare system is heterogeneous in nature because the care of a patient largely depends on multiple stakeholders such as physicians of diverse specialties, radiologists, pharmacists, nurses and laboratory technologists. The healthcare system is also data intensive in nature because the diverse stakeholders generate, store, retrieve and use data from diverse sources such as clinical data and insurance claims. Hence, the data generated by a healthcare provider is usually needed by another for decision making. Consequently, healthcare providers exchange information. This process and the nature of the data it contains which include insurance and payment information makes healthcare data susceptible to fraud, waste and abuse such as information theft. Furthermore, the voluminous nature of healthcare data, the enormous volume of money involved in the healthcare system as well as the inadequacy of surveillance and monitoring systems make the healthcare system attractive to fraud, waste and abuse [1]. Fraud, waste and abuse however have grievous consequences on healthcare system which makes it substantial to financial loss and also prevent healthcare providers from providing quality and safe care to legitimate patients [2]. Consequently, effective fraud, waste and abuse detection technologies are important for improving the quality of healthcare as well as reducing the cost of healthcare services [1]. Fraud detection typically involves identifying fraud as quickly as possible once it has been perpetrated [3]. Typical fraud detection methods used in the healthcare system include auditing strategies and data mining methods. The basic advantages of fraud detection methods include automatic learning of fraud patterns from data, specification of fraud likelihood as well as

\footnotetext{
* Corresponding author, tel: +234 - $803-510-2875$
} 
the identification of new types of fraud [1]. In spite of the significance of fraud detection methods, the detection of fraud, waste and abuse in the healthcare system still remains a challenge as new fraud patterns are constantly been developed to circumvent fraud detection methods [4]. In addition, not much academic attention has been paid to fraud, waste and abuse in healthcare due to confidentiality and privacy issues as well as the dynamic nature of fraud and changes in legislation over time [5]. Hence, the healthcare system is characterized by increased cost and low quality healthcare services. In view of this, this paper examines the methods of detecting fraud, waste and abuse in the healthcare system. This is with a view to revealing their strengths and limitations as well as identifying new areas for further research.

The remainder of this paper is structured as follows: section 2 describes the research methodology; section 3 summarizes the evidences from the selected studies, section 4 describes the strengths and limitations of the study while section 5 concludes the study.

\section{RESEARCH METHODOLOGY}

In general, the major goal of this study was to systematically identify, analyze, evaluate and interpret studies in fraud, waste and abuse detection methods in healthcare. This was with a view to obtaining enough evidences on the ways fraud, waste and abuse are committed in the healthcare system and the different techniques of fraud detection in healthcare. The 5-step approach proposed by Khan et al. [6] was adopted for this research. The approach consists of five basic steps which are depicted in Figure 1.

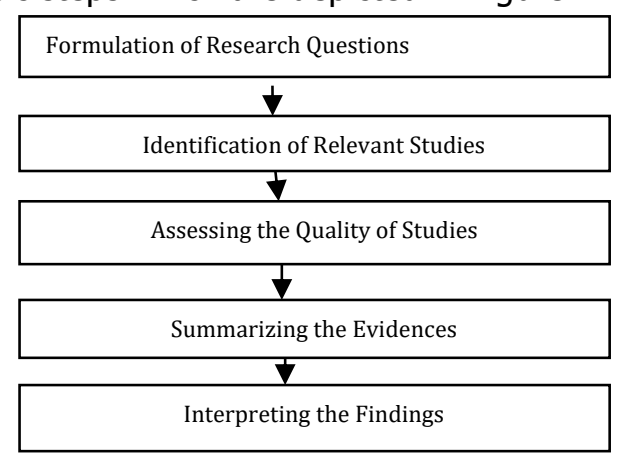

Figure 1: The research framework

\subsection{Formulation of Research Questions}

The research problem was specified in clear, structured and unambiguous questions. This was with the view to summarizing evidences as regards the techniques for fraud, waste and abuse detection in healthcare. In view of this, the following research questions were formulated:

$\bullet$

hat are the typical types of fraud, waste and abuse in healthcare?

$\bullet$

hat are the consequences of fraud, waste and abuse in healthcare?

hat are the laws and policies that have been put in place to prevent fraud, waste and abuse in healthcare?

\section{-}

hat are the techniques used for the detection of fraud, waste and abuse in healthcare?

-

hat are the benefits and limitations of the techniques identified?

\subsection{Identification of Relevant Studies}

An extensive search of relevant literatures was carried out. The goal of the literature search was to develop a comprehensive list of potentially relevant studies [7]. This was to ensure that the systematic review was comprehensive, thorough and objective. A wide range of studies were searched to identify primary studies in three scientific electronic databases namely CiteseerX, Science Direct and Google scholar. Furthermore, the Google search engine was searched for documents and WebPages that contained relevant references for the study. The keywords used during the search process were basically derived from the research questions. Some of the keywords include "healthcare fraud", "healthcare abuse", "fraud, waste and abuse in healthcare", "techniques for fraud detection in healthcare", benefits of fraud detection methods in healthcare" and "limitations of fraud detection methods in healthcare". The search was with language restriction because the review focused only on literatures published in English Language. Hence, papers that were not written in English Language and that did not contain necessary information such as the year of publication and the names of the journals were excluded from the study. A total of 1545 studies were obtained from the search process. The potential relevance of each of the study was examined by their titles and at the end of this process 187 studies were selected for the study while 1358 papers were excluded from the review process because they did not have any direct link with the research questions. Furthermore, papers that were replicated in two or 
more of the databases and the search engine were also excluded from the study. However, a version of such paper was kept aside for the review process. In order to minimize the risk of missing relevant literature, a manual search of the bibliographies of the selected papers was carried out. Thirteen papers that met the research objectives were realized from this exercise. At the end of this exercise, a total of 200 papers were selected for the review process.

\subsection{Assessing the Qualities of the Studies}

The full papers of the 200 studies were analyzed in order to select the primary studies relating to fraud, waste and abuse detection methods in healthcare. The relevance and quality of each of the papers were assessed based on the following critical appraisal guidelines.

- Are the objectives of the study related to the research?
- Are the objectives clearly defined?

- Are the techniques identified in the paper explicit?

- Does the paper contribute to the body of industrial and research knowledge?

The qualities of these papers were assessed in a blinded fashion by not putting into consideration the name of the journal, authors and the institutions [7]. The quality of the papers was also appraised based on the answers to each of the appraisal guidelines. The study adopted the Likert scale as shown in Table 1 for scoring the responses to the criteria guidelines. This is because the Likert scale provides options for degree of opinions. Hence, the quality of a paper was determined by summing up the scores of the responses to the criteria guidelines using the Likert scale. The authors agreed that the qualities of the studies should be determined by considering papers with $50 \%$ score.

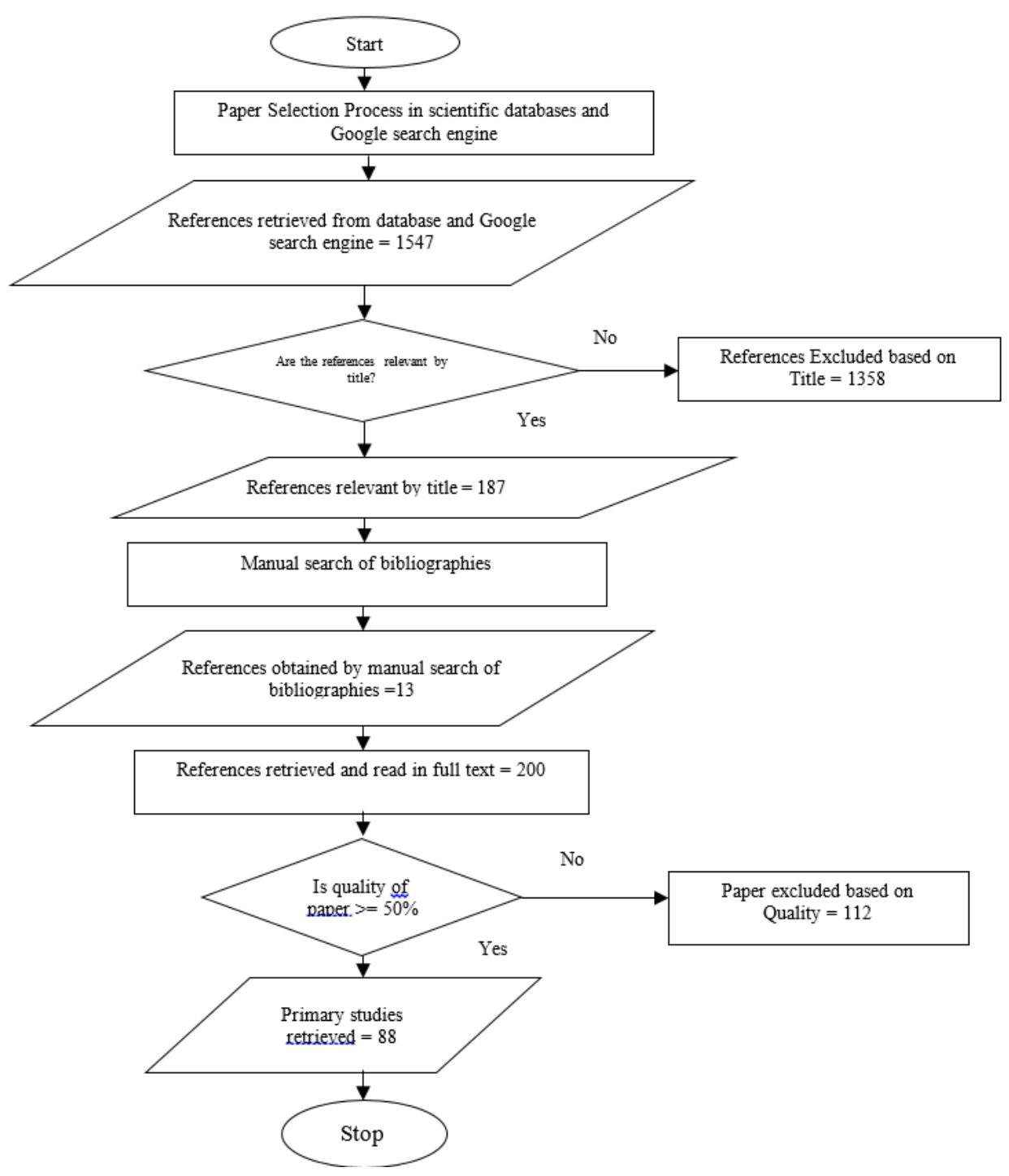

Figure 2. The Paper Selection Flowchart 
Table 1: The Likert scale used for the research

\begin{tabular}{cl}
\hline Score & \multicolumn{1}{c}{ Scale } \\
\hline 1 & Strongly disagree \\
2 & Disagree \\
3 & Undecided \\
4 & Agree \\
5 & Strongly agree \\
\hline
\end{tabular}

This process excluded 112 papers from the review process while 88 papers were eventually selected for the systematic review. Thirteen (13) papers were obtained from CiteSeer X, twelve (12) each from Science Direct and Google scholar while fifty one (51) papers were obtained from the Google search engine. Figure 2 shows the paper selection flowchart while Figure 3 shows the statistics of the selected papers from the electronic databases and the Google search engine after scrutiny.

Number of Relevant Studies

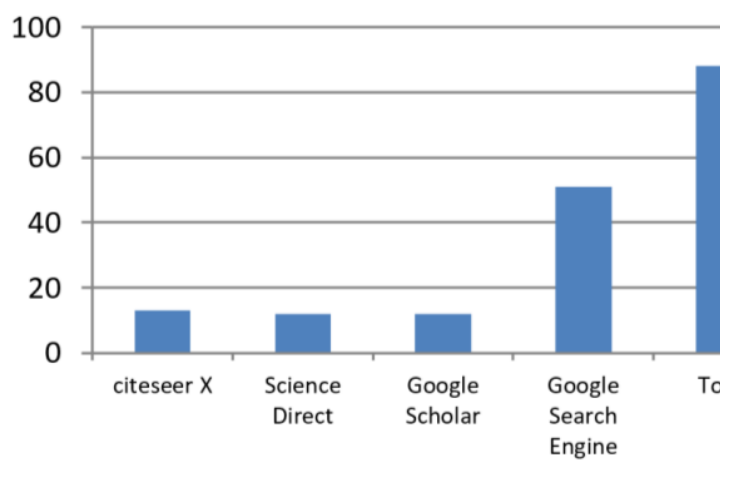

Scientific Databases

Figure 3: Number of Relevant Studies after Scrutiny

\section{RESULTS AND DISCUSSIONS}

This section summarizes the evidences from the selected papers in order to address the research questions. It also presents the overview of the selected studies as well as the answers to each of the research questions. The data related to each of the research questions were organized in a consistent and logical manner.

\subsection{Overview of the Selected Studies}

Out of the eighty eight (88) selected papers, seventy two (72) were journal articles, one (1) was a book, seventeen (11) were conference proceedings, two (2) were white papers, and two (2) were post graduate theses. The percentages of the selected studies were depicted in the pie chart in Figure 4 and Figure 5 depicts the number of publications obtained by their year of publications. The years of publication of the papers were between 1984 and 2016. This was because the earliest published paper amongst the selected papers was in 1984 .
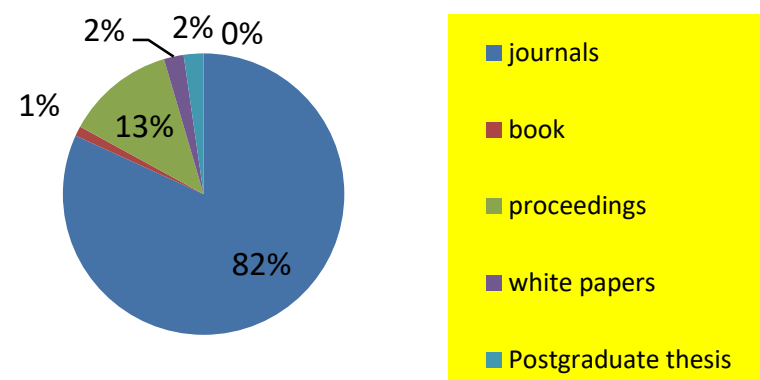

Figure 4. A Pie Chart Depicting the Percentages of the Selected Studies

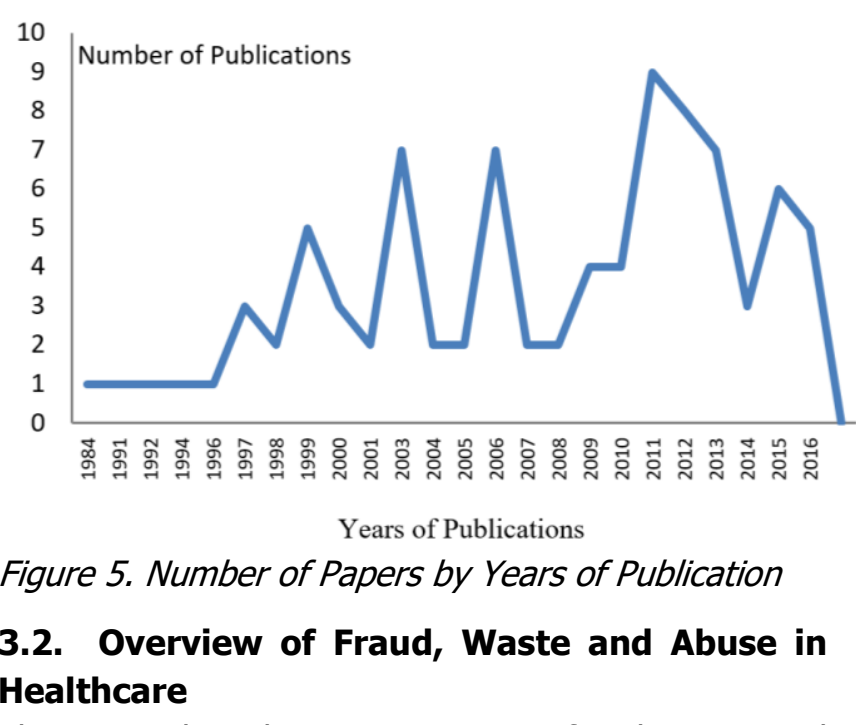

There is a clear distinction amongst fraud, waste and abuse, although these terms are usually used interchangeably. The Association of Certified Fraud Examiners (ACFE) defined fraud as the use of one's occupation for personal enrichment through the deliberate misuse or application of the employing organization's resources or assets [8]. Hence, fraud is a criminal deception, dishonesty, trick and the use of false representations to gain an advantage. Abuse can be viewed as the improper use or misuse of resources. Waste is the unnecessary or wrong use of resources. From the definitions above, it can be deduced that fraud, waste and abuse involve the improper or ineffective use of resources. However, the major distinction amongst these three terms is the intension behind the actions. The National HealthCare Anti-fraud Association [9] defines healthcare fraud as an intentional deception or misrepresentation made by a person or an entity with the knowledge that the deception could result in unauthorized benefits to the 
person or entity. Sparrow [12] classified healthcare fraud as hit-and-run and steal a little. Hit-and-run refers to the strategy in which a fraudster bills a healthcare organization and acquires large amount of money quickly and disappears before anyone realizes what happens. Steal a little involves the fraudulent act of billing a healthcare organization unnoticed over a long period of time. Healthcare fraud according to Li. J. [1] involves three basic parties. These include service providers such as doctors, hospitals and laboratories; insurance subscribers such as patients and patients' employers; and insurance carriers such as governmental health departments and private insurance companies. The term abuse in the context of healthcare can be used to describe the problematic behavior of a physician or a healthcare organization that is not clearly against the law [10]. The National HealthCare Anti-Fraud Association (NHCAA) emphasized that healthcare abuse occurs when healthcare practices are inconsistent with sound fiscal, business or medical practices which results in unnecessary cost or reimbursement of services that are not medically necessary or that fail to meet professionally recognized standards $[9,13]$. Waste refers to the consumption of healthcare services or practices carelessly or thoughtlessly. Waste according to Humana [11] is not caused by criminally negligent actions, but by the misuse of resources. Figure. 6 shows the distinction amongst fraud, waste and abuse.

\subsection{Types of Fraud, Waste and Abuse in Healthcare}

Thirty types of fraud, waste and abuse were identified from the selected studies. It was discovered from the studies that healthcare fraud encompasses a wide range of illicit practices ranging from identity theft, duplicate billing, kickback referrals to billing for medical services not rendered otherwise known as phantom billing. Table 2 shows the types of fraud, waste and abuse in the healthcare system.

\begin{tabular}{|c|c|c|}
\hline WASTE & ABUSE & FRAUD \\
CAUSED BY & CAUSED BY & CAUSED BY \\
INEFFICIENCIES & BENDING THE & INTENTIONAL \\
& RULES & DECEPTION \\
\hline
\end{tabular}

Figure 6. Differences amongst Fraud, Waste and Abuse in Healthcare

Table 2: Types of fraud, waste and abuse in healthcare

\begin{tabular}{|c|c|c|c|}
\hline Scheme & Description & Strategy & Citations \\
\hline Medical Identity Theft & $\begin{array}{l}\text { This involves the stealing of healthcare } \\
\text { providers or beneficiaries identification and } \\
\text { using the information to submit fraudulent bills }\end{array}$ & Fraud & [14-18] \\
\hline Fictitious Practitioner & $\begin{array}{l}\text { This involves enrolling and submitting bills on } \\
\text { behalf of fictitious practitioners }\end{array}$ & Fraud & {$[14-16,19]$} \\
\hline Phantom Billing & $\begin{array}{l}\text { This involves the submission of claims for } \\
\text { services not provided }\end{array}$ & Fraud & [17-25] \\
\hline Duplicate Billing & $\begin{array}{l}\text { This involves the submission of similar claims } \\
\text { more than once }\end{array}$ & $\begin{array}{l}\text { Fraud } \\
\text { Abuse }\end{array}$ & $\begin{array}{l}{[12,15,20,} \\
21,26]\end{array}$ \\
\hline Bill Padding & $\begin{array}{l}\text { This involves the submission of claims for } \\
\text { unneeded ancillary services }\end{array}$ & $\begin{array}{l}\text { Fraud } \\
\text { Abuse }\end{array}$ & {$[14-16,22]$} \\
\hline Upcoding & $\begin{array}{l}\text { This involves billing for a service with a higher } \\
\text { reimbursement rate than the service provided }\end{array}$ & $\begin{array}{l}\text { Fraud } \\
\text { Abuse }\end{array}$ & $\begin{array}{l}{[2,14,15} \\
21,22]\end{array}$ \\
\hline Unbundling & $\begin{array}{l}\text { This involves the submission of several claims } \\
\text { for various services that should only be billed } \\
\text { as one master claim }\end{array}$ & $\begin{array}{l}\text { Fraud } \\
\text { Abuse }\end{array}$ & $\begin{array}{l}{[2,12,14-} \\
16,22,27, \\
28]\end{array}$ \\
\hline $\begin{array}{l}\text { Preventable conditions and } \\
\text { avoidable care }\end{array}$ & $\begin{array}{l}\text { An example is the use of expensive resources } \\
\text { during a patient's care that could have been } \\
\text { avoided with proper and usually less expensive } \\
\text { and preventive care. }\end{array}$ & Waste & [29] \\
\hline
\end{tabular}




\begin{tabular}{l} 
Scheme \\
\hline Misrepresenting services with \\
incorrect Current Procedural \\
Terminology (CPT) codes \\
Altering claim forms for higher \\
payments \\
Falsifying medical diagnoses \\
or procedures to maximize \\
payments
\end{tabular}

Kickback

Incorrect dates

Medications without examination

Self-referral

Doctor shopping

Off-label promotion of drugs

False negotiation frauds-inthe-inducement.

Using Wrong diagnosis

Services rendered by unqualified personnel

Lying about eligibility

Reverse false claim

Waiving co-payments

Performing unnecessary medical services

Conspiracy
Description

This occurs when healthcare services are misrepresented by classification codes.

This occurs when medical claims are fraudulently modified in order to gain higher payment

This involves the falsification of information in medical records in order to maximize payment

This is a form of negotiated bribery in which a commission is paid to the provider or patient as a quid pro quo for services rendered

This includes reporting claims with incorrect dates that could be prior to or after the Strategy Citations beginning of an insurance period This is the issuance of invoices for medications without medical examination

Fraud

This involves referring patients to a clinic with which the referring physician has a financial relationship

Example involves a drug-seeking person who looks for another doctor that provides his desired prescriptions.

This involves the marketing of drugs that are not approved by the Food and Drug

Fraud

Fraud $[2,26,20$, 30]

Fraud $[2,16,20$, 22]

Fraud

Fraud

Fraud

$[2,16]$

Administration.

This arises when a healthcare provider makes false statements to induce the government to enter into a contract for services or supplies. These are caused by claims that are submitted for a service provided based on manipulated diagnosis

This is caused by care that are provided by people who do not have the credentials or license to actually perform that kind of care This involves misrepresenting information about patients in order to get insurance coverage

This occurs when a care provider owes the government and does not pay it back on time This involves an insurance plan requiring copayments for certain services to incentivize patients in order to make appropriate cost

Fraud $[16,36]$ minded decisions

An example is recommending an ultrasound test for a muscle sprain without adequate proof that it was medically necessary

Fraud Abuse This occurs when a patient colludes with his physician in order to fabricate medical service

Fraud 


\begin{tabular}{|c|c|c|c|}
\hline Scheme & Description & Strategy & Citations \\
\hline & $\begin{array}{l}\text { and to deceive the insurance company he is } \\
\text { subscribed with }\end{array}$ & & \\
\hline Ghost employees & $\begin{array}{l}\text { This involves keeping deceased individuals or } \\
\text { fake employees on healthcare providers' } \\
\text { payroll }\end{array}$ & Fraud & {$[16]$} \\
\hline Bait and switch pricing & $\begin{array}{l}\text { This occurs when a beneficiary is led to believe } \\
\text { that a drug will cost one price, but at the point } \\
\text { of sale the beneficiary is charged a higher } \\
\text { amount }\end{array}$ & Fraud & {$[17]$} \\
\hline Resale of drugs & $\begin{array}{l}\text { Beneficiary falsely reports loss or theft of drugs } \\
\text { or fakes illness to get drugs for resale on black } \\
\text { market. }\end{array}$ & Fraud & [17] \\
\hline Misrepresented status & $\begin{array}{l}\text { Beneficiary misrepresents personal information } \\
\text { to illegally receive benefit }\end{array}$ & Fraud & {$[17]$} \\
\hline $\begin{array}{l}\text { Dispensing expired or } \\
\text { adulterated prescription drugs }\end{array}$ & $\begin{array}{l}\text { Pharmacies dispense drugs that are expired or } \\
\text { have not been stored or handled in accordance } \\
\text { with manufacturers' requirements. }\end{array}$ & Fraud & {$[17]$} \\
\hline
\end{tabular}

\subsection{Consequences of fraud, waste and abuse in healthcare system}

Table 3 shows the consequences of fraud, waste and abuse on the healthcare system. Fraud and abuse account for $3-10 \%$ of the annual expenditures of the United States healthcare [38]. Hence, the estimated cost of fraud and abuse ranges from $\$ 100-170$ billion annually [19]. In addition to the huge financial loss, fraud hinders the healthcare system from providing quality care to legitimate beneficiaries [2].

\subsection{Laws and policies guiding against fraud, waste and abuse in healthcare system}

A lot of laws and policies have been put in place to curb fraud, waste and abuse in healthcare. This is as a result of the high cost of healthcare services as well as the low quality of healthcare services delivered to patients. Table 4 shows the laws and policies that guide against fraud, waste and abuse in the healthcare system.

Table 3: Effects of fraud, waste and abuse on the healthcare system

\begin{tabular}{ll}
\hline Consequences & Citations \\
\hline Huge financial loss to the government, service providers, insurance companies, patients & {$[2,14,20,39$,} \\
and their employers & $40-61]$ \\
Deny patients medically necessary services & {$[20,42,62]$} \\
Poses threat to the health and safety of individuals & {$[20]$} \\
Creates a paper trail of fictitious treatments that can adversely affect employment & {$[20,63]$} \\
opportunities and deny consumers access to healthcare services & {$[42,45]$} \\
Lack of quality care & {$[42,62]$} \\
Results in services that fail to meet professionally recognized healthcare standards & {$[64]$} \\
Hinders patients from providing sufficient information to their healthcare providers & {$[64]$} \\
Results in low willingness of patients and healthcare providers to cooperate & {$[28]$} \\
Increases health insurance rates, making health care unaffordable & \\
\hline
\end{tabular}


Table 4: Laws and policies guiding against fraud, waste and abuse in the healthcare system

\begin{tabular}{|c|c|c|c|}
\hline Law & Description & Penalty & Citation \\
\hline $\begin{array}{l}\text { False Claims Act of } \\
1986\end{array}$ & $\begin{array}{l}\text { This imposes civil and criminal liability on } \\
\text { individuals who submit false claims to the } \\
\text { government }\end{array}$ & $\begin{array}{l}\text { Violators are liable to a } \\
\text { statutory penalty of } \\
\$ 5,500 \text { to } \$ 11,000\end{array}$ & $\begin{array}{l}{[20,64,} \\
65]\end{array}$ \\
\hline $\begin{array}{l}\text { Operation Restore } \\
\text { Trust (ORT) }\end{array}$ & $\begin{array}{l}\text { It is an antifraud initiative designed to } \\
\text { fight fraud and abuse in Medicare }\end{array}$ & Violators are liable to fine & {$[40]$} \\
\hline $\begin{array}{l}\text { Anti-Kickback Statute } \\
\text { (AKS) }\end{array}$ & $\begin{array}{l}\text { This does not allow individuals to induce } \\
\text { services reimbursable by a Federal } \\
\text { healthcare program }\end{array}$ & $\begin{array}{l}\text { Fines, imprisonment or } \\
\text { both }\end{array}$ & $\begin{array}{l}{[20,54,} \\
66]\end{array}$ \\
\hline $\begin{array}{l}\text { The Health Insurance } \\
\text { Portability and } \\
\text { Accountability Act of }\end{array}$ & $\begin{array}{l}\text { This protects the privacy of an individual's } \\
\text { identity and medical records }\end{array}$ & $\begin{array}{l}\text { Fines, imprisonment or } \\
\text { both }\end{array}$ & {$[17,20]$} \\
\hline $\begin{array}{l}\text { Physician Self-Referral } \\
\text { Law (Stark Law) }\end{array}$ & $\begin{array}{l}\text { This prohibits a physician from making a } \\
\text { referral for certain designated health } \\
\text { service to an entity in which the physician } \\
\text { has an ownership or a compensation } \\
\text { arrangement unless an exception applies }\end{array}$ & $\begin{array}{l}\text { Fines, repayment of claims } \\
\text { and potential exclusion } \\
\text { from participating in all } \\
\text { Federal healthcare } \\
\text { programs }\end{array}$ & {$[54]$} \\
\hline $\begin{array}{l}\text { Criminal Health Care } \\
\text { Fraud Statute }\end{array}$ & $\begin{array}{l}\text { This prohibits individuals from executing a } \\
\text { scheme in connection with the payment } \\
\text { for healthcare services to defraud a } \\
\text { healthcare benefit program }\end{array}$ & $\begin{array}{l}\text { Fines, imprisonment or } \\
\text { both }\end{array}$ & [54] \\
\hline $\begin{array}{l}\text { Civil Rights of } \\
\text { Institutionalized } \\
\text { Persons Act of } 1980\end{array}$ & $\begin{array}{l}\text { This Act secures the rights of individuals } \\
\text { who are institutionalized. }\end{array}$ & Fines & {$[20]$} \\
\hline $\begin{array}{l}\text { Racketeer Influenced } \\
\text { and Corrupt } \\
\text { Organization Act } \\
\text { (RICO) }\end{array}$ & $\begin{array}{l}\text { This Acts allows consumers to sue health } \\
\text { insurers for damages under the federal } \\
\text { racketeering law }\end{array}$ & Fines & {$[20,67]$} \\
\hline
\end{tabular}

\subsection{Fraud, waste and abuse detection methods in healthcare system}

There are two basic methods of detecting fraud in the healthcare system. These methods include the audit method and data mining techniques [43]. Auditing strategies according to Copeland [43] is the use of trained personnel to evaluate the processes in the healthcare system while data mining methods rely on large data sets to identify potential anomalies. The major limitation of the auditing strategy is that it is inaccurate, costly and time consuming [68]. Data mining methods are classified as supervised, unsupervised and semi-supervised methods [3]. Supervised methods require samples from both known fraudulent and non-fraudulent records so as to model the distinct characteristics of both fraudulent and nonfraudulent records. The major advantage of supervised learning is that all outputs manipulated by the algorithm are meaningful to humans, and it can be easily used for discriminative pattern classification [3]. Supervised models however cannot detect new types of fraud because the models are created from past fraud strategies. In addition, it is expensive to hire medical experts to review large numbers of claims [22]. Unsupervised methods, on the other hand, do not require any prior knowledge of the relative legitimacy of the data and the data is unlabeled [43]. Unsupervised methods for fraud detection in healthcare use technology to identify potentially fraudulent transactions, and then require the use of expertise to determine the legitimacy of those transactions [43]. These methods are more cost effective than supervised method and they can detect new types of fraud [2]. The semi-supervised methods combine the features of both the supervised and the unsupervised method. In other words, these methods make use of labeled data which are pre-identified and also evaluate unlabeled data during processing [69]. The semi-supervised method achieves better performance by utilizing both labeled and unlabeled data [22]. Extensive research has conducted for fraud detection in healthcare using the data mining approaches. Table 5 provides an overview of these techniques. 
Table 5: Fraud detection methods in the healthcare system

\begin{tabular}{|c|c|c|c|}
\hline Method & Description & Benefit/Limitation & Citation \\
\hline $\begin{array}{l}\text { Fuzzy logic } \\
\text { supervised } \\
\text { approach }\end{array}$ & $\begin{array}{l}\text { It assigns data to a particular } \\
\text { group based on the possibility } \\
\text { that the data is in that group }\end{array}$ & $\begin{array}{l}\text { It gives room for approximate } \\
\text { reasoning but lacks effective learning } \\
\text { capability }\end{array}$ & {$[70]$} \\
\hline $\begin{array}{l}\text { Neural networks } \\
\text { supervised } \\
\text { approach }\end{array}$ & $\begin{array}{l}\text { These are sets of interconnected } \\
\text { nodes that imitate the } \\
\text { functioning of the brain }\end{array}$ & $\begin{array}{l}\text { It learns data without the knowledge } \\
\text { of potential data principles in advance. } \\
\text { The input to neural networks is } \\
\text { numeric and may be complicated with } \\
\text { non scalar fields }\end{array}$ & [71-74] \\
\hline $\begin{array}{l}\text { Bayesian } \\
\text { Networks } \\
\text { supervised } \\
\text { approach }\end{array}$ & $\begin{array}{l}\text { This provides a graphic model } \\
\text { of causal relationships on which } \\
\text { class membership probabilities } \\
\text { are predicted }\end{array}$ & $\begin{array}{l}\text { They are accurate and fast to train but } \\
\text { slower when applied to new instances }\end{array}$ & {$[75,76]$} \\
\hline $\begin{array}{l}\text { Clustering } \\
\text { analysis } \\
\text { unsupervised } \\
\text { approach }\end{array}$ & $\begin{array}{l}\text { It discovers groups and } \\
\text { structures in the data that are } \\
\text { similar without using known } \\
\text { structures in the data }\end{array}$ & $\begin{array}{l}\text { It allows similar data to be grouped } \\
\text { together which facilitates the easy } \\
\text { identification of patterns in the data } \\
\text { but provides less precision and not } \\
\text { very robust towards outliers }\end{array}$ & {$[77-82]$} \\
\hline $\begin{array}{l}\text { Visualization } \\
\text { histogram } \\
\text { unsupervised } \\
\text { approach }\end{array}$ & $\begin{array}{l}\text { This involves the use of graphs } \\
\text { and pictures that contains a lot } \\
\text { of information and provides the } \\
\text { user with useful patterns and } \\
\text { trends. }\end{array}$ & $\begin{array}{l}\text { It detects trends and outliers which } \\
\text { discovers irregularities in the data but } \\
\text { requires large amount of memory }\end{array}$ & [83] \\
\hline $\begin{array}{l}\text { Outlier detection } \\
\text { unsupervised } \\
\text { approach }\end{array}$ & $\begin{array}{l}\text { This method detects outliers/ } \\
\text { anomaly that are inconsistent } \\
\text { with the remainder of that data } \\
\text { set }\end{array}$ & $\begin{array}{l}\text { It has the potential to detect new } \\
\text { fraud but outliers may occur due to } \\
\text { erroneous recording of data }\end{array}$ & [84-88] \\
\hline $\begin{array}{l}\text { Link and Basket } \\
\text { Algorithm }\end{array}$ & & & \\
\hline
\end{tabular}

\section{STRENGTHS AND LIMITATIONS OF THE STUDY}

This study provides a systematic review of fraud, waste and abuse in healthcare. The study identified the different types of fraud, waste and abuse exhibited in the healthcare system and also provides a distinction amongst fraud, waste and abuse in healthcare. The study identified the consequences of fraud, waste and abuse in healthcare as well as the policies and laws that curb fraud, waste and abuse in healthcare. Several techniques that have been used for detecting fraud, waste and abuse were also discussed in this study. The study also pointed out the benefits and limitations of each of these techniques. However, this study was limited to studies that were published in English Language. Hence, relevant studies published in other languages relating to fraud, waste and abuse in healthcare must have been exempted from the systematic review.

\section{CONCLUSION}

The major goal of this study was to systematically identify, analyze and interpret studies on fraud, waste and abuse detection in healthcare. This was with a view to obtaining enough evidences on the diverse types of fraud, waste and abuse in healthcare, the consequences of fraud, waste and abuse in healthcare, the laws, policies and penalties of fraud in healthcare as well as the techniques for detecting fraud in healthcare. The study reviewed eighty eight (88) primary studies relating to fraud, waste and abuse in healthcare. It was discovered from the studies that there are a lot of fraudulent behaviors exhibited within the healthcare system in spite of the laws and policies 
put in place to curb fraud, waste and abuse. It was also discovered that quite a number of techniques are used to detect fraud patterns in healthcare. In spite of this, new fraud patterns are constantly been developed to circumvent these fraud detection methods. Hence, further research should focus on how the overall performance of each of the fraud detection techniques could be improved.

\section{REFERENCES}

[1] J. Li, K.Y., Huang, J. Jin and, J. Shi, "A survey on statistical methods for health care fraud detection", Health Care Management Science, vol. 11, pp. 275-287, 2008.

[2] T. Ekin, F. Ieva, F. Ruggeri and R. Soyer, "Statistical issues in medical fraud assessment", Modelling and Scientific Computing. MOX-Report No. 28/2013, 2013.

[3] R. J. Bolton, and D. J. ,"Hand Statistical fraud detection: A review", Statistical Science, pp. 235249, 2002.

[4] J. Liu, E. Bier, A. Wilson, T. Honda, S. Kumar, L. Gilpin, J. Guerra-Gomez, and D. Davies, "Graph analysis for detecting fraud, waste, and abuse in healthcare data", Twenty-Seventh Conference on Innovative Applications of Artificial Intelligence, 2015.

[5] C. Phua, V. Lee, K. Smith, and R. Gayler, , "A comprehensive survey of data mining-based fraud detection research", Arxiv Preprint, 2010.

[6] K.S. Khan, R. Kunz, J. Kleijnen, and G. Antes, "Five steps to conducting a systematic review", Journal of the Royal Society of Medicine, vol. 96, pp. 118121, March 2003.

[7] R.W. Wright, R.A. Brand, W. Dunn, and K.P. Spindler, "How to write a systematic review", Clinical Orthopaedics and Related Research, pp. 23-29, 2007.

[8] Y. Kou, C.T. Lu, S. Sirwongwattana, and Y.P. Huang, "Survey of fraud detection techniques", Networking, sensing and control, pp. 749-754. 2004.

[9] National Health Care Anti Fraud Association, "What is health care fraud?" http://www.nhcaa.org/resources/health-careanti-fraudresources/consumer-info-action.aspx, 2012.

[10]H. Torras, "Healthcare fraud and abuse: A physician's guide to compliance"., American Medical Association Press. 2006.
[11] Humana, "Addressing fraud, waste, and abuse", http://www.humana.com/about/legal/disclaimerand-licensure/fraud-waste-and-abuse, 2016.

[12] M.K. Sparrow, "License to steal: How fraud bleeds America's healthcare system", Westview Press, Boulder, 2000. Westview Press, Boulder, 2000.

[13]S. Maes, K. Tuyls, B. Vanschoenwinkel, B. Manderick, "Credit card fraud detection using Bayesian and neural networks", First International Naiso Congress on Neuro Fuzzy Technologies, 2002.

[14] P. Travaille, D. Thornton, R.M. Muller, "Electronic fraud detection in the U.S. medicaid healthcare program: Lessons learned from other industries",17th Americas Conference on Information Systems, pp. 1-10. 2011

[15] GAO. "United States general accounting office health care fraud: Schemes to defraud medicare, medicaid, and private health care insurer", T-OSI00-15, 2000.

[16]D. Thornton, M. Brinkhuis, C., Amrit, and R. Aly, "Categorizing and describing the types of fraud in healthcare", Health and Social Care Information Systems and Technologies, vol. 64, pp. 713-720, October, 2015.

[17] BlueCross BlueShield, "Fraud, waste and abuse, BlueCross BlueShield, South Carolina, 2009.

[18]E. Litchko, "Prevention and early detection of health care fraud, waste, and abuse", National Health Policy Forum, 2009.

[19]W. Rudman, "Healthcare fraud and abuse", Perspectives in Health Information Management, pp. 1-24, 2009.

[20] L.M. Jackson, " Efforts to combat health care fraud: A study of NYSE listed health care service companies", Lubin School of Business, Pace University,1999

[21]Q. Liu and M. Vasarhelyi, " Healthcare fraud detection: A survey and a clustering model incorporating geo-location information", 29th world continuous auditing and reporting symposium (29WCARS), 2013.

[22] A. Abdallah A. M., Maaroof Z. A , "Fraud detection system: A survey", Journal of Network and Computer Applications, vol. 68, pp. 90-113, 2016.

[23]D. Thornton, R. M. Mueller, P.,Schoutsen, J. Van fegersberg, "Predicting healthcare fraud in medicaid: A multidimensional data model and analysis techniques for fraud detection", Procedia Technology, vol. 9, pp.1252-1264, 2003. 
[24]TIBC. "Combating fraud, waste, and abuse in healthcare". A White Paper on Fraud, Waste, and Abuse in Healthcare. TIBCO Software Inc, 2015.

[25]P. A. Gutiérrez, C. Hervás-Martínez and F. J. Martínez-Estudillo, "Logistic regression by means of evolutionary radial basis function neural networks", IEEE Transactions on Neural Networks, vol. 22, pp. 246-263, 2011.

[26] K. Ilker, G, Mehmet, and K. Kemal, "An interactive machine-learning-based electronic fraud and abuse detection system in healthcare insurance", Applied Soft Computing, vol. 36, pp. 283299,2015.

[27]G. Capelleveen, M. Poel, R. M. Mueller, D. Thornton, and J Hillegersberg, "Outlier detection in healthcare fraud: A case study in the Medicaid dental domain", International Journal of Accounting Information Systems, vol, 21, pp. 1831, 2016.

[28]S. Furlan, and M. Bajec, "Holistic approach to fraud management in health insurance", Journal of Information and Organizational Sciences, vol. 32, pp. 99- 114, 2008.

[29]B. Kelley and M.D. Fabius, "A path to eliminating $\$ 3.6$ trillion in wasteful healthcare spending", $A$ White Paper. Thomson Reuters., USA, 2010.

[30]W.J. Rudman, "Implementation of outcomes measures and statistical process control methodologies in quality assurance and utilization review efforts within health information management departments", Topics in Health Information Management, pp. 1-7, 1998.

[31] R. Doan, "False claims act and the eroding scienter in healthcare fraud litigation", The Annals Health, 2011.

[32]G. A. Ogunbanjo, and van B. D. Knapp, "Ethics in healthcare: healthcare fraud: ethics CPD supplement", South African Family Practice, vol. 56, pp. S10-S13, 2014

[33] J. D. Byrd, P. Powell, and D. L. Smith, "Healthcare fraud: An introduction to a major cost issue", Journal of Accounting, Ethics and Public Policy, 2013

[34]D. Thornton, G. van Capelleveen, M. Poel, J. van Hillegersberg, and R. Mueller, "Outlier-based health insurance fraud detection for U.S. Medicaid Data", 16th International Conference on Enterprise Information System, pp. 684-694, 2014.

[35] G. Borca, "Technology curtails health care fraud" Managed Care, vol. 4, 2001.
[36] B. A. Freeman, and A. Loavenbruck, "Complying with healthcare fraud laws: An overview for the hearing professional," The Hearing Journal, vol. 54 , 2001.

[37]J. Hossein, R. Arash,, M., Behrouz, M., Bidgoli, G. Bijan, N. Mahdi, and A Mohammad, "Using data mining to detect health care fraud and abuse: A review of literature", . Global Journal of Health Science; vol. 7,pp. 194-202, 2015

[38]T. Ekin, F. Leva, F. Ruggeri, and R. Soyer, " Application of bayesian methods in detection of healthcare fraud", Chemical Engineering Transactions, vol. 33, pp. 151-156, 2013

[39] National Healthcare Antifraud Association Report, http://www.nhcaa.org/resources/health-careanti-fraudresources/consumer-info-action.aspx, 2008.

[40] P. Travaille, "Electronic fraud detection in the U.S. Medicaid Health Care Program" University of Twente, The Netherand, 2011.

[41]A. Miller, "The government crackdown on medicare fraud is saving millions of dollars, but some contend it's going too far", The Atlanta Constitution, 1999

[42] P. Ortega, C., Figueroa, and G.Ru, "A medical claim fraud/abuse detection system based on data mining: A case study in Chile", Proceedings of DMIN, pp. 224-231, 2006

[43]L. Copeland, "Applying business intelligence concepts to Medicaid claim fraud detection", "Information Systems Applied Research", 2011.

[44]T. J. Heaphy, "Healthcare Fraud". http://www.justice.gov/usao/vaw/health care fra ud/, 2011.

[45] American Hospital Association,"Healthcare fraud report fiscal year" U.S. Justice Department, 2011.

[46] J. T. Wells, "Principles of fraud examination", John Wiley and Sons, 2005.

[47] Price Waters Coopers, "Global economic crime survey Technical report", Price Waterhouse Coopers, 2005.

[48], D. Thornton, R. M. Mueller, P. Schoutsen, J. van fegersberg, "Predicting healthcare fraud in medicaid: A multidimensional data model and analysis techniques for fraud detection", Procedia Technology, vol. 9, pp, 1252-1264, 2013.

[49] G. Brooks, M. Button, and J. Gee, "The scale of healthcare fraud: A global evaluation: , Security Journal, vol. 25,pp. 76-87, 2012

[50] J. D. Byrd, P. Powell, and D. L. Smith, "Healthcare fraud: An introduction to a major cost issue" 
Journal of Accounting, Ethics and Public Policy, vol. 14, 2013.

[51] R.P. Kusserow, "The government needs computer matching to root out waste and fraud", Communications of the ACM, vol. 27,pp. 542545,1984 .

[52]J., Hossein, R. Arash, M. Behrouz, M Bidgoli, G. Bijan, N. Mahdi, and A. Mohammad, " Improving fraud and abuse detection in general physician claims: A data mining study", International Journal of Health Policy and Management, vol. 5,pp. 165-172, 2016

[53]M. K. Sparrow, "Fraud in the US health-care system: Exposing the vulnerabilities of automated payments systems," Social research, pp. 11511180,2008

[54]U.S. Department of Health and Human Services," A comprehensive strategy to fight health care waste, fraud, and abuse", www.hhs.gov/news/ press/2000pres/2000309a.html, 2000.

[55]S. Agrawal, B. Tarzy, L. Hunt, J. Taitsman, and P. Budetti, " Expanding physician education in health care fraud and program integrity", Academic Medicine, vol. 88, pp. 1081-1087, 2013

[56]A. Rashidian, H. Joudaki, and T. Vian, "No evidence of the effect of the interventions to combat health care fraud and abuse: A systematic review of literature", . PLOS ONE, H. R. Baradaran, ed. 2012.

[57] M. Button, G Brooks, and P. Vincke, " The financial cost of healthcare fraud", University of Portsmouth, MacIntyre Hudson, Milton Keynes, 2010.

[58] M.,Kirlidoga and C.Asukb, "A fraud detection approach with data mining in health insurance", Procedia - Social and Behavioral Sciences, vol. 62, pp.989 - 994, 2012

[59]M. K. Sparrow, "Healthcare fraud control understanding: The challenge", Journal of Insurance Medicine, vol. 28, pp. 86-96. 1996.

[60]U.S. General Accounting Office, "Health insurance: vulnerable payers lose billions to fraud and abuse", GAO/HR-92-69, 1992.

[61]GAO, "Testimony before the Committee on Homeland Security and Governmental Affairs", http://www.gao.gov/new.items/d09453t.pdf, 2008.

[62] National HealthCare Anti-Fraud Association., "Guidelines to health care fraud", http://www.nhcaa.org, 1991

[63]T. L. Chin, "Health insurers turn to software for fraud busting", Health Data Management, 1997.
[64] K. Lin and C. Yeh, "Use of data mining techniques to detect medical fraud in health insurance, International Journal of Engineering and Technology Innovation", vol. 2, pp. 126-137, 2012.

[65]D.A. Hyman, "HIPAA and health care fraud: An empirical perspective", Cato Journal, vol. 22 , 2002.

[66] Cotton and Company, L.L.P., "Brief synopses of major government fraud statutes", http://www.cottoncpa.com/laws.htm., 1999.

[67] H. Burghardt, 'RICO cause of action against McosHumana inc. v. Forsyth", American Journal of Law and Medicine, 1999

[68]W.S. Yang and S.Y. Hwang, "A process-mining framework for the detection of healthcare fraud and abuse". Expert Systems with Applications, vol. 31, pp. 56-68, 2006

[69] N. Laleh, and M.A.Azomi, "A taxonomy of frauds and fraud detection techniques", In Proceedings of the third International Conference, S.K. Prasad, S. Routray, R. Khurana and S. Sahni (eds.), Springer, India, pp. 256-267. 2009.

[70]K Cox,., nd Wills G., "Viual data mining: Recognizing telephone calling fraud", Data Mining and Knowledge Discovery, vol. 1, pp. 225-231, 1997

[71] P.L. Brockett, R.A, Derrig, L.L., Golden, A. Levine, and M. Alpert, "Fraud classification using principal component analysis of RIDITs", Journal of Risk and Insurance, vol. 69, pp. 341-371, 2002.

[72] H. Kim, S. Pang, H. Je, D. Kim and S Bang., "Constructing support vector machine ensemble", Pattern Recognition vol. 36 , pp. 2757-2767, 2003

[73]P. Brockett and L Golden, "A comparison of neural network, statistical methods, and variable choice for life insurers' financial distress pre diction", Journal of Risk Insurance, vol. 73,pp. 397-419, 2006.

[74] W.A Wong, G. Cooper, and M. Wagner," Bayesian network anomaly pattern detection for detecting disease outbreaks", In Proceedings of ICML.,2003

[75] J. Han, M Kamber, and J. Pei, "Data mining: Concepts and techniques", Morgan Kaufmann, 2006

[76] P. Chan, W. Fan, A. Prodromidis, and S. Stolfo, "Distributed data mining in credit card fraud detection", IEEE Intelligent Systems vol.14, pp. 67-74, 1999.

[77] H. Shan and A. Banerjee, "Bayesian co-clustering", In Proceedings of 8th IEEE International Conference on Data Mining, pp. 530-539 2008 
[78]M.Tang, B. Mendis, U. Sumudu, D., Murray, H. Wayne, and S.A. Yingsong,. "Unsupervised fraud detection in Medicare" Australia.103-110.

[79] R. M. Musal, "Two models to investigate Medicare fraud within unsupervised databases, Expert Systems with Applications, vol. 37, pp. 8628-8633, 2010.

[80]Q. Liu, and M. Vasarhelyi, "Healthcare fraud detection: A survey and a clustering model incorporating Geolocation information" In Proceedings of 29th World Continuous Auditing and Reporting Symposium, 2013.

[81]G. J. Williams and Z. Huang, "Mining the knowledge mine. Advanced Topics in Artificial Intelligence", Springer Berlin Heidelberg, pp. 340348, 1997

[82]D. Monali, and S. R. .Siddharth,."Study and analysis of data mining algorithms for healthcare decision support system" International Journal of Computer Science and Information Technologies, vol. 5,pp. 470-477, 2014

[83]E.N. Argyriou, and A. Symvonis, "Detecting periodicity in serial data through visualization",
Advances in Visual Computing. Vol. 7432,pp. 295304, 2012.

[84]Y. Peng, G. Kou, A. Sabatka, J Matza,, Z. Chen, D. Khazanchi, and Y. Shi, "Application of classification methods to individual disability income insurance fraud detection", Computational Science-ICCS, pp. 852-858. 2007.

[85] K. Yamanishi, T.. Ichi, G. Williams, and P. Milne, "On-line unsupervised outlier detection using finite mixtures with discounting learning algorithms", Data Mining and Knowledge Discovery, vol. 8, pp. 275-300, 2004.

[86]Y. Shan, D. M. Jeacocke, D.Wayne, and A. Sutinen, "Mining medical specialist billing patterns for health service management", In Proceedings of the 7th Australasian Data Mining Conference, vol. 87, pp. 105-110, 2008.

[87] V. Barnett, and T. Lewis "Outliers in statistical data", John Wiley and Sons, Chichester, 1994.

[88]M. Agyemang, K. Barker, and R. Alhajj," A comprehensive survey of numeric and symbolic outlier mining techniques", Intelligent Data Analysis, vol. 10, pp. 521-538, 2006. 